\title{
Food allergy knowledge, attitudes, and practices of food handlers working in the five-star hotel kitchens in Turkey
}

\author{
Uğur LOKMAN1, Aylin AKOĞLU²
}

Cite this article as:

Lokman, U., Akoğlu, A. (2022). Food allergy knowledge, attitudes, and practices of food handlers working in the five-star hotel kitchens in Turkey. Food and Health, 8(1), 23-34. https://doi.org/10.3153/FH22003

\footnotetext{
1 Istanbul Gedik University, Faculty of Fine Arts and Architecture, Department of Gastronomy and Culinary Arts, İstanbul Turkey

2 Abant Izzet Baysal University, Faculty of Health Sciences, Department of Nutrition and Dietetics, Bolu, Turkey
}

RCID IDs of the authors:

U.L. 0000-0002-3004-2303

A.A. $0000-0002-0136-4928$

Submitted: 12.06 .2021

Revision requested: 15.07 .2021

Last revision received: 26.07.2021

Accepted: 29.07.2021

Published online: 19.11.2021

Correspondence:

Uğur LOKMAN

E-mail: ugur.lokman@gedik.edu.tr

\begin{abstract}
The purpose of this study is to determine the food allergy knowledge, attitudes and practices of food handlers working in five-star hotel kitchens in Turkey and to explore the association between the obtained scores and handlers' demographic and working characteristics. A cross-sectional survey involving 450 food handlers in the state of Istanbul, Ankara and Antalya, in Turkey, was conducted using a paper-based questionnaire. The total knowledge score of the participants was $11.89 \pm 2.22(\max 17)$, attitude score $60.63 \pm 10.34(\max 75)$ and practice score $55.60 \pm 8.01(\max$ $65)$. In the comparison based on demographic characteristics; the knowledge $(12.10 \pm 2.15)$ and practice $(56.33 \pm 5.91)$ scores of the food handlers who received food allergy training in the hotel they work were found to be significantly higher than those who did not receive food allergy training $(\mathrm{p}<0.05)$. Food allergy knowledge of food handlers was evaluated as "average", attitude as "positive", and practice as "low risk practice". The results obtained are expected to contribute to the development of food allergy policies, procedures, and the planning of the necessary trainings for reducing the risks of food allergies and preventing fatal allergic reactions.
\end{abstract}

Keywords: Food allergy, Knowledge, Attitude, Practices, Food handlers, Hotel kitchen

\section{(c) (1)}




\section{Introduction}

Allergy has become one of the major problems in Western societies in the 20th century. There are estimated 220-250 million people worldwide affected by allergic diseases. Food allergy accounts for a significant part of allergic diseases (Olivier, 2013). It has been increasing in prevalence in the last 2 to 3 decades (Seth et al., 2020). Changes in the environment, lifestyle, and dietary habits (Sicherer, 2011) may have resulted in the increase of food allergies. Sicherer and Sampson (2014) stated that food allergy cases are mostly encountered in the United States. It is estimated that approximately 15 million people in the USA, 5.9 million of which are children, have food allergies (FARE, 2020). It is reported that one in every 17 children in England and 10 children in Australia has food allergy; while one out of every 17 children in Turkey have food allergy, although this varies according to region (Güler, 2019). In Turkey, as in the world, the prevalence of food allergies increases gradually (Sapan et al., 2013).

Food allergy is an excessive (abnormal-adverse) reaction initiated by the immune system to a particular food (Boyce, 2012). It has been reported that the only way to prevent reactions in case of food allergy is to remove the food that evokes the allergy from the diet (Stjerna et al., 2014). In an individual with food allergy, an allergic reaction occurs a few minutes or hours after exposure to the allergen food. While some symptoms of food allergic reactions are mild (i.e., rashes, itching, and swelling), the severe reaction known as anaphylactic shock could be lethal (National Institute of Allergy and Infectious Disease, 2019). It is estimated that every year, food allergies are responsible for roughly 30,000 medical emergencies and 150-200 deaths in the U.S. (Sampson, 2004). In addition to their life-threatening nature, allergic reactions also cause psychological problems such as increased anxiety, demoralization, limited socialization, and decreased quality of life (Gaspar-Marques et al., 2014).

Eating out is dangerous for an individual with food allergy. Providing allergen-free food to customers with food allergies is difficult as eating out habits and the prevalence of food allergies are increasing (Kwon and Lee, 2012). There are a range of factors that could potentially lead to food allergic reactions, including cross-contact, miscommunication between wait staff and cooks, ingredients not listed by restaurants on menus, and contact with food residuals. In addition, incomplete food labels and hidden allergens in mixed dishes can also lead to allergic reactions to food (Lee and Barker, 2016). Taking these factors into consideration, it is evident that food handlers play a key role in preventing food allergies (Shafie and Azman, 2015). A food handler is a person who is directly involved in preparing food, in contact with food or food contact surfaces and/or handles packaged or unpackaged food or appliances in any food premise. Food handlers in hotel consist of cooks. It is essential that these individuals should possess sufficient knowledge, attitude and practice level about food allergy and should realize the due importance of the issue very well. The best practice to achieve this is to provide food allergy training in parallel with food safety training to relevant food handlers. However, previous research has shown that many food handlers receive no or very little food allergy training (Ahuja and Sicherer, 2007; Lee and Barker, 2016; Lee and Sozen, 2016; Mandabach et al., 2005; Wen and Kwon, 2017).

Hotels, being an important branch of the tourism sector, provide catering for millions of people. Hence, food safety, hygiene, and sanitation are the most critical issues need to be considered by hotel management. If due attention is not paid for these issues during the preparation and service of the food, it might cause health threats for both staff and the customers (Baser et al., 2017). It is necessary to reveal the current situation and to identify the deficiencies in order to take corrective actions. Understanding these gaps will help plan and implement policies and training that will benefit both administrative staff and employees.

In parallel with the significant increase in fatal cases of allergic reactions, the issue of food allergy has attracted the attention of public health authorities, particularly regarding the practice among food handlers. The high knowledge, attitude, and practice of food handlers regarding food allergies have a very important effect in preventing possible reactions. For this purpose, many studies have been conducted to measure the food allergy knowledge, attitude and practice of restaurant employees (Ahuja and Sicherer, 2007; Bailey et al., 2014; Choi and Rajagopal, 2013; Common et al., 2013; Lee and Barker, 2016; Shafie and Azman, 2015; Sogut et al., 2015; Tatlı and Akoğlu, 2020; Wen and Kwon, 2017), however, no previous study has been found to measure the knowledge, attitude and practice of employees in hotels. The purpose of this study is to measure the food allergy knowledge, attitude and practice of the food handlers working in five-star hotels in Turkey. The findings to be reached are expected to help making suggestions on the subject and taking measures. 


\section{Materials and Methods}

\section{Research Design and Participants}

Since the tourism sector is a service sector and the hotel workers are busy in the summer season, this study was held between December and May 2018 which are off-peak period. A total of 540 questionnaires were collected; however, 450 eligible questionnaires were used for data analysis since 90 were excluded due to missing data. The sample consists of 450 food handlers working in five-star hotels located in three major cities of Istanbul, Ankara and Antalya which are among the three largest cities in Turkey and also have high tourism potential. For the research to reach $95 \%$ confidence level, the number of 384 that corresponds to 100.000-1.000.000 sample interval was taken as basis (Lorcu 2015), and our sample size was considered sufficient since it was larger than this value. Participants were selected by simple random sampling method. While individuals who were literate and worked as executive chef, assistant chef, section chef, chef, comi and steward staff were included in this study, individuals who did not wish to enroll in the research voluntarily, had less than six months of work experience, and could not speak and understand Turkish were not included. The participants were informed about the purpose and content of the study and the researchers obtained written consent forms from the participants. The Ethics Committee of Human Studies in Social Sciences of Abant Izzet Baysal University approved the study (no: 2018/21).

\section{Questionnaire Design}

The questionnaire form was developed using related resources and some previous studies on the issue (Choi and Rajagopal, 2013; Shafie and Azman, 2015; Dupuis et al., 2016; Soon, 2019). The questionnaire constructed and divided into four sections. The first section of the questionnaire solicited demographic information from the participants. Second section consisted of 17 items to evaluate food allergy knowledge. The scores on the food allergy knowledge questions were recorded as " 1 " for a correct answer and " 0 " for an incorrect answer. As an appendix to this section, an extra part comprising 13 items to measure food handlers' knowledge of the most eight common food allergens were added. The third section contained 15 items that assessed food allergy attitudes using a 5-point Likert scale, ranging from one (1) "Strongly disagree" to five (5) "Strongly agree". The fourth section contained 13 items that assessed food allergy practice using a 5point Likert scale $(1=$ Never, $2=$ Rarely, $3=$ Sometimes, 4 $=$ Usually, $5=$ Always). Accordingly, knowledge score was evaluated within a range of $0-17$, attitude score 15-75, and practice score 13-65.

\section{Data Analysis}

The data obtained was analyzed using Statistical Package for Social Sciences (SPSS) version 20. Descriptive statistics including frequencies, percentage distributions, means, and standard deviations were used to evaluate demographic characteristics. Cronbach's coefficient of reliability was calculated and found as 0.64 (knowledge), 0.91 (attitude) and 0.81 (practice), and these values were determined to be sufficient in terms of reliability (Ural and K1lıç, 2013). Normality test was performed using the Kolmogorov-Smirnov test. Kruskal Wallis and Mann Whitney $U$ test were used to examine significant differences in food allergy knowledge, attitudes, and practices on demographic characteristics. Games-Howell and Tamhane's T2 non-parametric post-hoc tests were conducted to determine within group differences. Spearman's correlation coefficient was used to test the association between knowledge, attitudes and practices scores of the participants. Findings with a p-value $<0.05$ were considered to be statistically significant.

The scoring scale applied in the study of Shafie and Azman (2015) was used to evaluate the mean score ranges of the knowledge, attitude, and practice. The score for each section was converted to a percentage by dividing the total score by the maximum score obtainable and the obtained values were assessed over three ranges. The first range, which was $<25$ was interpreted as poor knowledge/negative attitude/high risk practice, the second range, 25-75 as moderate knowledge/moderate attitude and moderate risk practice, and the third range, $>75$ was excellent knowledge/positive attitude and low risk practice.

\section{Results and Discussion}

\section{Sample Characteristic}

Demographic characteristics of participants were shown in Table 1. Percentage of male participants $(71.8 \%)$ is higher than that of female (28.2\%). Nearly half of participants (44\%) are high school graduates. The majority of participants consist of section chefs $(28.9 \%)$ and the chefs $(38.7 \%)$. When examined with regards to age ranges, nearly half of participants (46.2\%) range between 25-34 years of age. In terms of years of service in the profession; it was identified that $18.7 \%$ is in food business for $1-5$ years, $36.4 \%$ for $6-10$ years, $20.7 \%$ for $11-15$ years, $14 \%$ for $16-20$ years and $10.2 \%$ for 21 years and more. It was determined that $60.3 \%$ of participants received food allergy training at workplace. It was found that the majority of participants $(77.3 \%)$ had not been exposed to food allergies. 
Table 1: Demographic characteristics of participants $(n=450)$

\begin{tabular}{llll}
\hline Variable & Items & Frequency & \% \\
\hline \multirow{3}{*}{ Cities } & Antalya & 200 & 44.4 \\
& Istanbul & 150 & 33.3 \\
Gender & Ankara & 100 & 22.3 \\
& Male & 323 & 71.8 \\
Age & Female & 127 & 28.2 \\
& $\leq 24$ & 57 & 12.7 \\
& $25-34$ & 208 & 46.2 \\
Education level & $35-44$ & 139 & 30.9 \\
& 45 years and above & 46 & 10.2 \\
& Primary school & 78 & 17.3 \\
Position & Secondary school & 95 & 21.1 \\
& High school & 44 \\
& Undergraduate/postgraduate & 198 & 17.6 \\
Have & Executive Chef & 19 & 4.2 \\
Have you received training on food allergies at workplace? $?$ & Assistant Chef & 25 & 5.6 \\
& Section Chef & 130 & 28.9 \\
Hork experience & Chef & 174 & 38.7 \\
& Comi & 89 & 19.7
\end{tabular}

Total Food Allergy Knowledge, Attitudes and Practices Score by Respondent Characteristic

The total knowledge, attitude and practice scores of the food handlers and the differences among these scores according to demographic characteristics as shown in Table 2. As a result of the analysis, Cronbach $\alpha$ coefficients were found as 0.64 (knowledge), 0.91 (attitude) and 0.81 (practice), and these values were determined to be sufficient in terms of reliability (Ural and Kılıç, 2013).

The mean knowledge score of participants was $11.89 \pm 2.22$ (max 17), the attitude score $60.63 \pm 10.34(\max 75)$ and the practice score $55.60 \pm 8.01$ (max 65). Expressing these results in percentage terms (Shafie and Azman, 2015); it was determined that the participants had moderate knowledge (70\%), positive attitude (81\%) and low risk practices $(86 \%)$. It was found that the food allergy attitude scores of the participants significantly varied based on the cities where the business is located $(\mathrm{p}<0.05)$. A significant difference was found between the food allergy knowledge and attitude scores with respect to the age range of the participants $(\mathrm{p}<0.05)$. Food allergy knowledge ( $\overline{\mathrm{x}}: 11.12)$ and attitude ( $\overline{\mathrm{x}}: 56.23)$ scores of food handlers under the age of 24 were found to be significantly lower than those aged 25 and over. A significant difference was found among the food allergy knowledge scores of the participants based on their education level $(p<0.05)$. It was determined that the knowledge scores of primary school graduates ( $\mathrm{x}: 10.88)$ were significantly lower than those with secondary, high school, undergraduate and higher education $(\overline{\mathrm{x}}: 11.42,11.77,12.26$, respectively). There was a significant 
difference among the food allergy attitude and practice scores of the participants with respect to their workplace positions $(\mathrm{p}<0.05)$. The food allergy attitude $(\overline{\mathrm{x}}: 64.52)$ score of the executive chefs was found to be significantly higher. A significant difference was identified among the food allergy practice scores of the participants with respect to their work experience $(p<0.05)$. It was determined that the food allergy practice scores of the food handlers with 16-20 ( $\mathrm{x}: 57.10)$ and 21 years or more $(\overline{\mathrm{x}}: 57.17)$ work experience were significantly higher than those with 15 years or less. A significant difference was determined among the food allergy knowledge and practice scores of the participants with respect to whether they received any food allergy training at workplace $(p<0.05)$. Food allergy knowledge $(\bar{x}: 12.10)$ and practice $(\overline{\mathrm{x}}: 56.33)$ scores of food handlers who received food allergy training at workplace were found to be significantly higher than those with no training ( $\overline{\mathrm{x}}: 10.78$ and $\overline{\mathrm{x}}: 54.18$, respectively). A significant difference was found among the food allergy attitude scores of the participants based on their exposure to food allergy $(\mathrm{p}<0.05)$. The attitude scores of food handlers exposed to food allergy ( $\mathrm{x}: 64.52)$ were found to be significantly higher than those with no exposure experience $(\overline{\mathrm{x}}: 60.82)$.

\section{Total Food Allergy Knowledge Score}

The distribution of food handlers' responses to the statements on food allergy knowledge as shown in Table 3. Participants gave mostly correct answers to statements about the definition of food allergy (93.3\%), the importance of food allergy $(96.2 \%)$, and allergic reactions $(90.2 \%)$. They gave poor answers to the statements of "Food allergy is like food intolerance", "Lactose intolerance is like milk allergy", and "Food allergy can be result in death in severe cases" $(40.9 \%, 50.2 \%$, and $60.4 \%$, respectively).

The capability of participants to select the eight most common allergens as shown in Table 4. Many participants managed to identify egg $(93.3 \%)$, milk $(90.2 \%)$, shellfish $(86.4 \%)$, fish $(81.3 \%)$, wheat $(80.9 \%)$ and soy $(80.7 \%)$ as six of the most common allergens, but not peanuts and tree nuts, which were identified by only $59.1 \%$ and $52.2 \%$ of the participants, respectively. A significant majority of the participants $(90.7 \%)$ included gluten in the most common allergens group, although it was not an allergen.

\section{Total Food Allergy Attitude Score}

The distribution of participants' responses to the food allergy attitude statements as shown in Table 5. Participants' attitude towards the "importance of studies on food allergy" has the highest mean score $(4.50 \pm 0.90)$, while the attitude regarding the capability to effectively manage a food allergy emergency in the kitchen has the lowest mean score $(3.76 \pm 1.32)$.

\section{Total Food Allergy Practices Score}

The distribution of participants' responses to the practice statements as shown in Table 6. The mean score of the food handlers for food allergy practice was $4.36 \pm 1.02$ on a fivepoint Likert scale. Participants had the highest mean score $(4.67 \pm 0.80)$ on personal hygiene and the lowest mean score $(3.60 \pm 1.02)$ on cross-contact.

\section{Association among knowledge, attitudes, and practices of food allergy}

Summary of correlation for the levels of knowledge, attitudes and practices as shown in Table 7. A significant weak positive correlation was observed between knowledge and attitude ( $\mathrm{rs}=0.242, \mathrm{p}<0.01)$, knowledge and practice $(\mathrm{rs}=0.199$, $\mathrm{p}<0.01)$, and attitude and practice $(\mathrm{rs}=0.339, \mathrm{p}<0.01)$. The highest correlation was found to be between attitude and practice.

According to the findings obtained from the study, the knowledge score of the participants was determined as $70.9 \%$ (moderate), attitude score as $77.7 \%$ (positive) and practice score as $87.4 \%$ (low risk practice). Similarly, in the study of Shafie and Azman (2015) where they measured the food allergy knowledge, attitude, and practice of restaurant employees in Malaysia, the participants were found to have moderate knowledge $(50.23 \%)$, positive attitude $(54.26 \%)$ and moderate risk practice $(45.90 \%)$. Lee and Barker (2016), in their study with local restaurant staff in Alabama, determined that the food allergy knowledge score of the participants were moderate $(72.18 \%)$, similar to our study. Lefevre et al. (2018), different from this study and consistent with previous studies (Abbot et al., 2007; Ahuja and Sicherer, 2007; Bailey et al., 2014; Wen and Kwon, 2017; Wham and Sharma, 2014) reported that restaurant staff did not have sufficient knowledge about food allergy. 
Table 2: The mean scores for knowledge, attitude and practice by demographic characteristics

\begin{tabular}{|c|c|c|c|c|c|c|c|c|}
\hline \multirow{3}{*}{$\begin{array}{l}\text { Demographic } \\
\text { characteristic }\end{array}$} & \multirow[b]{3}{*}{ Items } & \multicolumn{3}{|c|}{ Knowledge } & \multirow{2}{*}{$\begin{array}{c}\text { Attitude } \\
\text { Mean } \pm \text { SD }\end{array}$} & \multicolumn{3}{|c|}{ Practice } \\
\hline & & n (\%) & Mean \pm SD & & & & Mean \pm SD & \\
\hline & & $450(100)$ & $11.89 \pm 2.22(0-17)$ & $\mathbf{p}$ & $61.11 \pm 11.20(15-75)$ & $\mathbf{p}$ & $55.60 \pm 5.28(13-65)$ & p \\
\hline \multirow{3}{*}{ Cities } & Antalya & $200(44.4)$ & $12.15 \pm 2.48$ & \multirow{3}{*}{0.061} & $58.54 \pm 12.81^{\mathrm{b}}$ & \multirow{3}{*}{0.050} & $56.54 \pm 4.86$ & \multirow{3}{*}{0.055} \\
\hline & İstanbul & $150(33.3)$ & $12.19 \pm 1.96$ & & $64.13 \pm 8.22^{\mathrm{a}}$ & & $56.08 \pm 5.76$ & \\
\hline & Ankara & $100(22.3)$ & $10.89 \pm 1.71$ & & $62.19 \pm 10.49^{a}$ & & $53.04 \pm 7.83$ & \\
\hline \multirow{3}{*}{ Gender } & Male & $323(71.8)$ & $11.93 \pm 2.24$ & \multirow{2}{*}{0.731} & $60.49 \pm 11.11$ & \multirow{2}{*}{0.405} & $55.11 \pm 5.82$ & \multirow{2}{*}{0.420} \\
\hline & Female & $127(28.2)$ & $11.86 \pm 2.21$ & & $60.98 \pm 11.47$ & & $55.80 \pm 6.67$ & \\
\hline & $\leq 24$ & $57(12.7)$ & $11.12 \pm 2.34^{b}$ & \multirow{4}{*}{0.012} & $56.23 \pm 12.84^{\mathrm{b}}$ & \multirow{4}{*}{0.010} & $55.44 \pm 6.25$ & \multirow{4}{*}{0.300} \\
\hline \multirow{3}{*}{ Age } & $25-34$ & $208(46.2)$ & $12.01 \pm 2.24^{\mathrm{a}}$ & & $60.95 \pm 11.04^{\mathrm{a}}$ & & $55.07 \pm 6.22$ & \\
\hline & $35-44$ & $139(30.9)$ & $12.00 \pm 2.05^{\mathrm{a}}$ & & $62.05 \pm 10.49^{a}$ & & $56.38 \pm 5.84$ & \\
\hline & $\geq 45$ & $46(10.2)$ & $12.28 \pm 2.29^{\mathrm{a}}$ & & $62.19 \pm 10.46^{\mathrm{a}}$ & & $55.77 \pm 5.80$ & \\
\hline \multirow{4}{*}{$\begin{array}{c}\text { Education } \\
\text { Level }\end{array}$} & Primary school & $78(17.3)$ & $10.88 \pm 1.61^{b}$ & \multirow{4}{*}{0.002} & $59.50 \pm 11.79$ & \multirow{4}{*}{0.528} & $55.00 \pm 6.71$ & \multirow{4}{*}{0.089} \\
\hline & Secondary school & $95(21.1)$ & $11.42 \pm 1.92^{\mathrm{a}}$ & & $61.71 \pm 10.77$ & & $56.32 \pm 5.06$ & \\
\hline & High school & $198(44)$ & $11.77 \pm 2.30^{\mathrm{a}}$ & & $60.48 \pm 12.11$ & & $55.19 \pm 6.17$ & \\
\hline & Undergraduate/postgraduate & $79(17.6)$ & $12.26 \pm 2.18^{a}$ & & $62.12 \pm 7.51$ & & $56.33 \pm 5.91$ & \\
\hline \multirow{6}{*}{ Position } & Executive Chef & $19(4.2)$ & $12.16 \pm 1.81$ & \multirow{6}{*}{0.098} & $64.52 \pm 6.42^{\mathrm{a}}$ & \multirow{6}{*}{0.010} & $57.28 \pm 5.73^{\mathrm{a}}$ & \multirow{6}{*}{0.034} \\
\hline & Assistant Chef & $25(5.6)$ & $12.10 \pm 2.15$ & & $61.01 \pm 8.33^{b}$ & & $56.04 \pm 6.21^{\mathrm{a}}$ & \\
\hline & Section chef & $130(28.9)$ & $11.91 \pm 2.25$ & & $61.65 \pm 10.74^{\mathrm{b}}$ & & $55.99 \pm 5.73^{\mathrm{a}}$ & \\
\hline & Chef & $174(38.7)$ & $11.42 \pm 1.92$ & & $60.43 \pm 11.85^{\mathrm{b}}$ & & $55.68 \pm 8.60^{\mathrm{a}}$ & \\
\hline & Comi & $89(19.7)$ & $11.36 \pm 2.40$ & & $57.90 \pm 14.23^{\mathrm{c}}$ & & $54.20 \pm 5.33^{b}$ & \\
\hline & Steward & $13(2.9)$ & $10.84 \pm 2.08$ & & $57.77 \pm 14.12^{\mathrm{c}}$ & & $54.18 \pm 5.59^{b}$ & \\
\hline \multirow{5}{*}{$\begin{array}{c}\text { Work } \\
\text { experience }\end{array}$} & $1-5$ years & $84(18.7)$ & $11.40 \pm 2.45$ & \multirow{5}{*}{0.121} & $59.00 \pm 12.79$ & \multirow{5}{*}{0.563} & $53.76 \pm 6.39^{c}$ & \multirow{5}{*}{0.002} \\
\hline & $6-10$ years & $164(36.4)$ & $11.95 \pm 1.99$ & & $61.09 \pm 10.87$ & & $55.78 \pm 5.61^{\mathrm{b}}$ & \\
\hline & $11-15$ years & $93(20.7)$ & $12.06 \pm 2.21$ & & $61.21 \pm 10.47$ & & $55.19 \pm 6.30^{\mathrm{b}}$ & \\
\hline & $16-20$ years & $63(14)$ & $12.19 \pm 2.27$ & & $61.77 \pm 10.22$ & & $57.10 \pm 6.51^{\mathrm{a}}$ & \\
\hline & $\geq 21$ years & $46(10.2)$ & $11.52 \pm 2.08$ & & $59.21 \pm 11.98$ & & $57.17 \pm 5.22^{\mathrm{a}}$ & \\
\hline Received & Yes & $272(60.3)$ & $12.10 \pm 2.15^{\mathrm{a}}$ & & $61.42 \pm 8.33$ & & $56.33 \pm 5.91^{\mathrm{a}}$ & \\
\hline $\begin{array}{c}\text { training on } \\
\text { food allergies } \\
\text { at workplace }\end{array}$ & No & 178 (39.7) & $10.78 \pm 2.48^{b}$ & 0.006 & $61.01 \pm 8.94$ & 0.478 & $54.18 \pm 6.21^{\mathrm{b}}$ & 0.017 \\
\hline Exposed to a & Yes & $102(22.7)$ & $11.64 \pm 2.21$ & & $64.52 \pm 6.42^{\mathrm{a}}$ & & $55.88 \pm 6.16$ & \\
\hline food allergy & No & $348(77.3)$ & $11.95 \pm 2.22$ & 0.138 & $60.82 \pm 11.70^{\mathrm{b}}$ & 0.023 & $55.52 \pm 6.06$ & 0.303 \\
\hline
\end{tabular}

Table 3: Food allergen knowledge $(n=450)$

\section{Questions}

A food allergy is an abnormal response of the immune system to an ordinarily harmless food or ingredient in a food.

Food allergies can adversely affect human health and may pose have serious consequences for some people.

Food allergens are usually proteins.

All steps from field to guest should be under control to avoid allergen cross-contact in foods

Food allergy can be serious but is not common

Food allergy is similar to food intolerance*

Food-allergic reactions occur within from 2 min to 12 hours

Spices are one of the most allergenic foods*

Individuals with food allergies can safely consume the foods that cause the allergies if only a small amount is consumed*

Cow milk is the most important and common allergic food for children.

Fish and seafood are allergic food for both adults and children.

Allergic reactions can be seen at the contact points of the food, such as lips or tongue, as well as throughout the body.

Lactose intolerance is similar to milk allergy*

Food allergy can be result in death in severe cases.

Cross-contact happens when one food meets another food and their proteins mix.

People with allergies come from families in which allergies are common.

High-temperature cooking such as roasting, baking and deep-frying can destroy food allergen
Correct answers

Frequency (\%)

$420 \quad 93.3$

433

96.2

344

76.4

409

90.9

356

184

272

179

40.9

60.4

286

39.8

330

63.6

322

406

226

272

357

351

73.3

71.6

90.2

50.2

60.4

79.3

78.0

279 
Table 4: The capability of participants to select the eight most common allergens

\begin{tabular}{|c|c|c|}
\hline Eight most common allergens & Frequency & $(\%)$ \\
\hline Peanuts ${ }^{*}$ & 266 & 59.1 \\
\hline Milk $^{*}$ & 406 & 90.2 \\
\hline Tomato & 196 & 43.6 \\
\hline Soy $^{*}$ & 363 & 80.7 \\
\hline Fruits & 173 & 38.4 \\
\hline Fish $^{*}$ & 366 & 81.3 \\
\hline Shellfish* & 389 & 86.4 \\
\hline Gluten & 408 & 90.7 \\
\hline Monosodium glutamate & 227 & 50.4 \\
\hline Sesame seed & 362 & 80.4 \\
\hline Egg* $^{*}$ & 420 & 93.3 \\
\hline Wheat ${ }^{*}$ & 364 & 80.9 \\
\hline Tree nuts ${ }^{*}$ & 235 & 52.2 \\
\hline
\end{tabular}

*Most common allergens

Table 5: Mean scores of items in attitude towards food allergy $(n=450)$

\begin{tabular}{|c|c|c|c|c|c|c|}
\hline \multirow{2}{*}{ Attitude Statements } & \multicolumn{5}{|c|}{ n (\%) } & \multirow[b]{2}{*}{ Mean \pm SD } \\
\hline & SD & D & $\mathbf{N}$ & $\mathbf{A}$ & $\mathbf{S A}$ & \\
\hline Food allergy is an important part of my job & $47(10.4)$ & $19(4.2)$ & $17(3.8)$ & $107(23.8)$ & $260(57.8)$ & $4.14 \pm 1.30$ \\
\hline $\begin{array}{l}\text { I believe I will prevent food allergy if employees are careful with food } \\
\text { allergens }\end{array}$ & $32(7.1)$ & $26(5.8)$ & $25(2.6)$ & $107(23.8)$ & $260(60.8)$ & $4.19 \pm 1.21$ \\
\hline $\begin{array}{l}\text { I am willing to attend food allergy training courses/workshops to learn } \\
\text { more about food allergies }\end{array}$ & $34(7.6)$ & $21(4.7)$ & $32(7.1)$ & $134(29.8)$ & $229(50.9)$ & $4.11 \pm 1.19$ \\
\hline $\begin{array}{l}\text { I do not think that enough information is given about food allergy in } \\
\text { the programs related to the field (gastronomy, cooking etc.) }\end{array}$ & $31(6.9)$ & $33(7.3)$ & $52(11.6)$ & $152(33.8)$ & $182(40.4)$ & $3.93 \pm 1.19$ \\
\hline $\begin{array}{l}\text { I think individuals involved in food preparation should be more } \\
\text { knowledgeable about food allergies }\end{array}$ & $17(3.8)$ & $24(5.3)$ & $27(6)$ & $134(29.8)$ & $248(55.1)$ & $4.27 \pm 1.04$ \\
\hline $\begin{array}{l}\text { I think the dishes made in the kitchen are reliable in terms of food al- } \\
\text { lergies }\end{array}$ & $25(5.6)$ & $38(8.4)$ & $37(8.2)$ & $\begin{array}{c}155 \\
(34.4)\end{array}$ & $195(43.3)$ & $4.01 \pm 1.16$ \\
\hline $\begin{array}{l}\text { I do not believe I can effectively handle a food allergy emergency situ- } \\
\text { ation at my workplace** }\end{array}$ & $45(10)$ & $44(9.8)$ & $56(12.4)$ & $133(29.6)$ & $172(38.2)$ & $3.76 \pm 1.32$ \\
\hline $\begin{array}{l}\text { I think the manager in my workplace should educate me about food al- } \\
\text { lergies and allergen handling }\end{array}$ & $18(4)$ & $23(5.1)$ & $31(6.9)$ & $158(35.1)$ & $220(48.9)$ & $4.19 \pm 1.04$ \\
\hline $\begin{array}{l}\text { I think, when allergic products are used in foods, the explanation about } \\
\text { these allergens should be stated on the food label }\end{array}$ & $19(4.2)$ & $14(3.1)$ & $33(7.3)$ & $143(31.8)$ & $241(53.5)$ & $4.27 \pm 1.02$ \\
\hline $\begin{array}{l}\text { I believe that food allergy will benefit both my work and my personal } \\
\text { life }\end{array}$ & $21(4.7)$ & $14(3.1)$ & $31(6.9)$ & $122(27.1)$ & $262(58.2)$ & $4.31 \pm 1.04$ \\
\hline $\begin{array}{l}\text { I believe that the disclosure of accurate allergen information to custo- } \\
\text { mers with a food allergy will decrease the likelihood of a food allergic } \\
\text { reaction }\end{array}$ & $23(5.1)$ & $14(3.1)$ & $30(6.7)$ & $143(31.8)$ & $240(53.3)$ & $4.25 \pm 1.06$ \\
\hline $\begin{array}{l}\text { I believe that knowledge about food allergies would make me more } \\
\text { confident about handling food at my workplace }\end{array}$ & $16(3.6)$ & $19(4.2)$ & $19(4.2)$ & $138(30.7)$ & $258(57.3)$ & $4.34 \pm 0.99$ \\
\hline $\begin{array}{l}\text { I believe appropriate precautions can be taken to avoid cross-contact } \\
\text { between foods at my workplace }\end{array}$ & $11(2.4)$ & $22(4.9)$ & $35(7.8)$ & $128(28.4)$ & $254(56.4)$ & $4.31 \pm 0.90$ \\
\hline $\begin{array}{l}\text { It is important to me that accurate information about food ingredients } \\
\text { is provided to customers with a food allergy }\end{array}$ & $207(46)$ & $130(28.9)$ & $56(12.4)$ & $22(4.9)$ & $35(7.8)$ & $3.96 \pm 1.19$ \\
\hline $\begin{array}{l}\text { I think studies on food allergy have an important place in order to en- } \\
\text { sure food safety }\end{array}$ & $11(2.4)$ & $13(2.9)$ & $24(5.3)$ & $93(20.7)$ & 309 (68.7) & $4.50 \pm 0.90$ \\
\hline
\end{tabular}

Scale for statements: $\mathrm{SD}=$ Strongly Disagree; $\mathrm{D}=$ Disagree; $\mathrm{N}=$ Neutral; A= Agree; $\mathrm{SA}=$ Strongly Agree

*SD; standard deviation

** Item was reversely coded 
Table 6: Mean scores of items in practice towards food allergy (1: Never to 5: Always) $(n=450)$

\begin{tabular}{|c|c|c|c|c|c|c|}
\hline \multirow[b]{2}{*}{ Practice Statements $(\alpha=0.81)$} & \multicolumn{6}{|c|}{ n (\%) } \\
\hline & Never & Rarely & Sometimes & Usually & Always & Mean \pm SD \\
\hline $\begin{array}{l}\text { I wash my hands thoroughly with soap and water and } \\
\text { wear a fresh pair of gloves before preparing an allergen- } \\
\text { free meal. }\end{array}$ & $12(2.7)$ & $2(0.4)$ & $24(5.3)$ & $69(15.3)$ & $343(76.1)$ & $4.62 \pm 0.83$ \\
\hline I wear clean uniforms in food preparation. & $22(4.9)$ & $9(2.0)$ & $12(2.7)$ & $76(16.9)$ & $331(73.8)$ & $4.52 \pm 1.05$ \\
\hline I use cap or bone when preparing food. & $9(2.0)$ & $11(2.4)$ & $9(2)$ & $61(13.5)$ & $360(79.8)$ & $4.67 \pm 0.80$ \\
\hline $\begin{array}{l}\text { I store allergen-free foods and allergen foods in the same } \\
\text { places. * }\end{array}$ & $225(50)$ & $60(13.4)$ & $25(5.5)$ & $41(9.1)$ & $99(22)$ & $3.60 \pm 1.07$ \\
\hline $\begin{array}{l}\text { If a mistake is made when preparing a meal for a food } \\
\text { allergic customer, I remake the food. }\end{array}$ & $17(3.8)$ & $11(2.4)$ & $19(4.2)$ & $109(24.2)$ & $294(65.2)$ & $4.44 \pm 0.96$ \\
\hline $\begin{array}{l}\text { When preparing fried food for patrons with a food al- } \\
\text { lergy, I make sure that I change the oil in the deep fryer } \\
\text { to prevent cross contact. }\end{array}$ & $28(6.2)$ & $17(3.8)$ & $13(3.1)$ & $108(23.9)$ & $284(63)$ & $4.32 \pm 1.12$ \\
\hline $\begin{array}{l}\text { I clean all the utensils before preparing food to prevent } \\
\text { cross-contact. }\end{array}$ & $6(1.3)$ & $20(4.3)$ & $16(4)$ & $103(22.8)$ & $305(67.6)$ & $4.51 \pm 0.85$ \\
\hline $\begin{array}{l}\text { I use separate equipment (tongs, ladles) for handling al- } \\
\text { lergen-containing foods. }\end{array}$ & $31(6.9)$ & $52(11.5)$ & $26(5.8)$ & $93(20.6)$ & $248(55.2)$ & $4.05 \pm 1.30$ \\
\hline $\begin{array}{l}\text { I use clean and sanitized equipment and utensils at my } \\
\text { workplace to prevent cross-contact between allergens. }\end{array}$ & $22(4.9)$ & $15(3.30)$ & $18(4)$ & $113(25.1)$ & $282(62.5)$ & $4.37 \pm 1.05$ \\
\hline I prepare allergen-free foods to prevent cross-contact. & $43(9.5)$ & $16(3.5)$ & $18(4)$ & $105(23.3)$ & $268(59.4)$ & $4.19 \pm 1.26$ \\
\hline $\begin{array}{l}\text { When preparing the eight most common food allergens, I } \\
\text { pay more attention to food processing practices. }\end{array}$ & $37(8.2)$ & $54(12)$ & $27(6)$ & $104(23.1)$ & $228(50.6)$ & $3.96 \pm 1.33$ \\
\hline $\begin{array}{l}\text { I check the ingredients and read the contents before us- } \\
\text { ing the packaged foods. }\end{array}$ & $15(3.3)$ & $12(2.7)$ & $20(4.4)$ & $93(20.6)$ & $311(69)$ & $4.49 \pm 0.94$ \\
\hline $\begin{array}{l}\text { If one of my customers has a food allergy, I check again } \\
\text { to make sure that the food is prepared safely and does } \\
\text { not contain allergens. }\end{array}$ & $26(5.8)$ & $20(4.4)$ & $19(4.2)$ & $105(23.3)$ & $280(62.1)$ & $4.31 \pm 1.12$ \\
\hline
\end{tabular}

* Item was reversely coded

Table 7: Correlation among knowledge, attitudes, and practices of participants $(n=450)$

\begin{tabular}{lllll}
\hline & & Knowledge & Attitude & Practice \\
\hline Knowledge & $\mathrm{R}$ & 1.000 & & \\
& $\mathrm{P}$ & 0.000 & & \\
Attitude & $\mathrm{R}$ & $0.242^{* *}$ & 1.000 & \\
& $\mathrm{P}$ & 0.000 & 0.000 & \\
Practice & $\mathrm{R}$ & $0.199^{* *}$ & $0.339^{* *}$ & 1.000 \\
& $\mathrm{P}$ & 0.000 & 0.000 & 0.000 \\
\hline
\end{tabular}

$*<0.05 ; * *<0.01$

In our study, the participants were able to define egg (93.3\%), milk $(90.2 \%)$, shellfish (86.4\%), fish (81.3\%), wheat (80.9\%) and soy $(80.7 \%)$ as the most common allergens at high percentages. As different results, in the studies of Tatli and Akoğlu (2020) and Sogut et al. (2015), which were conducted with restaurant staff in Turkey, it was reported that most participants were not able to identify the eight most common al- lergenic foods. Choi and Rajagopal (2013) reported that participants working in a university foodservice operation were knowledgeable about food allergy; however, most of them lacked knowledge about top eight food allergens from a particular allergen list.

In similar studies conducted on food allergy, areas that need improvement are like those in previous studies. One of them is the finding that the participants lacked a sufficient level of 
knowledge and practice on the difference between food allergy and food intolerance. Nonallergic food reactions, such as food intolerance, are commonly mistaken as food allergies (Seth et al., 2020). Features related to the ingredients of the food, or the enzymatic functions of the digestive system play a role in food intolerance. Food allergies affect the immune system, yet food intolerance affects the digestive system. While food intolerance is not life-threatening, food allergy can lead to death (FARE, 2020). Participants' poor rate of correct answers about the differences between food allergy and intolerance showed that they had insufficient knowledge on this subject. One of the most remarkable findings is that the vast majority of participants $(90.7 \%)$ included gluten in the most common allergen group, although it was not an allergen. This is another result supporting that the difference between food allergy and intolerance is not fully comprehended. Similarly, Kwon and Lee (2012) and Lee and Sozen (2018) found that employees lacked knowledge about the difference between food allergy and food intolerance. Another striking result is that almost half of the participants did not know that food allergy is a fatal reaction. In contrast, Dupuis et al. (2016) showed that nearly all restaurant staff participating in their study knew that food allergy is a fatal reaction. This result indicated that food handlers should definitely be made aware of this situation, which has such serious consequences.

In our study, it was observed that the participants received poor scores in effectively handling food allergy emergencies. Similarly, Madsen et al. (2010) indicated that food handlers without sufficient knowledge on food allergies were more likely to inappropriately handle food allergy emergencies or address the needs of allergic customers. Considering that the most serious food allergy reactions and fatalities occur among adults (Bock et. al., 2001), the emergency responds conducted by employees prove to be crucial.

As another aspect that needs to be fixed with the participants, it has been determined that there is a lack of knowledge and practice regarding cross-contact. It was determined that the participants received low scores regarding cross-contact in food allergy knowledge and practice statements. Similarly, Kwon et al. (2020) found that participants' food allergy knowledge in general was high $(82.3 \%)$, but they lacked sufficient knowledge about cross-contact. It is crucial for food handlers to have sufficient knowledge of cross-contact to reduce the risks posed by food allergies. On the other hand, individuals with food allergies should caution service staff about allergy while dining at the restaurant and share responsibility for preventing food allergy cases.

Food allergy knowledge and practice scores of food handlers who received food allergy training at workplace were found to be significantly higher than those with no training. In the study of Bailey et al. (2014), the knowledge level of employees officially with no former training on food allergy increased from $82 \%$ to $91 \%$ after food allergy training. In addition, the percentage of participants to identify at least three common allergens increased from $9 \%$ to $64 \%$. These results reveal the necessity of staff training in order to increase the level of knowledge on food allergy. Since there is still no obligation for food allergy training in Turkey, there is lack of training on the subject as seen in this study. In numerous studies, the significance of increasing food allergy knowledge of food service employees through education is particularly emphasized (Choi and Rajagopal, 2013; Shafie and Azman, 2015). Although it is highlighted that food allergy training should be given within the context of food safety trainings, there are some challenges in the implementation of food allergy training such as cost of training employees, high turnover, time constraints, and indifference of employees towards food allergies (Choi and Rajagopal, 2013).

In the correlation analysis, it was determined that the knowledge, attitude, and practice of the participants were correlated. A positive change in any of the variables leads to a positive change in other variables as well. Accordingly, it can be asserted that if the food handlers had sufficient knowledge about food allergy, this would reflect positively on their attitudes and practices. Therefore, kitchen managers in charge in the hotels should put emphasis on in-service training and raise food allergy awareness among staff. It is anticipated that such efforts may have a positive impact on practices in improving food allergy knowledge and that the higher level of attitude of the staff will also reflect on their practices. In a similar study, Tatlı and Akoğlu (2020) reported that the increase in food allergy knowledge level of restaurant employees will positively affect their attitudes and practices in ensuring food safety. Unlike this study, Ansari-Lari et al. (2010) reported that there is a positive correlation between knowledge-attitude but a negative correlation between knowledgepractice and attitude- practice. Similarly, Clayton et al. (2002), Seaman and Eves (2010) stated that food safety training is not effective on practice and attitude.

\section{Conclusion}

This study provided information on food allergy knowledge, attitudes and practices of the food handlers working in fivestar hotels in Turkey. Examining the participants' mean scores for knowledge, attitudes, and practices, it was found that they had moderate knowledge, positive attitude, and low risk practices. In addition, it was identified that the participants had deficiencies in particular issues such as cross-con- 
tact, effective handling of food allergy emergencies, the distinction between intolerance and allergy, and the consequences of allergic reactions. It was found that more than half of the food handlers received food allergy training and the fact that level of knowledge turned out to be moderate emphasizes the importance of training on food allergy. Results strongly emphasize the need for continuous interventions, training and regulations of food safety to enhance food handlers' knowledge and improve food safety in hotels. Food handlers working in hotels in Turkey attach importance to food allergies; however, necessary measures should be taken for a more effective implementation. Most of the research on food allergy in Turkey has been carried out made in the form of review articles or pediatrics studies. Survey-based studies aimed at measuring the knowledge, attitude and practice of food handlers mostly remained in the background. Therefore, in the future, such studies should be carried out to raise food allergy awareness. The recent increase in allergic diseases should be taken into consideration and due importance should be placed in this regard. It is necessary to draw attention to the fact that food allergies are a growing food safety and public health problem, and their prevalence in our country should be examined, individuals at risk should be identified, and preventive measures should be taken. The involvement of government agencies is also important for the development of educational campaigns for consumers regarding this issue.

\section{Compliance with Ethical Standard}

Conflict of interests: The author declares that for this article they have no actual, potential or perceived conflict of interests.

Ethics committee approval: "Abant İzzet Baysal University $\mathrm{Hu}-$ manities Ethics Committee in Social Sciences" was received on 24.01.2018 with the document number 2018/21.

\section{Funding disclosure:}

Acknowledgments: Authors are thankful for the hotel kitchen staff who participated in this research study. This study was a part of a Master Thesis of Uğur Lokman (Bolu Abant Izzet Baysal University, Department of Gastronomy and Culinary Arts).

Disclosure: Our study has some limitations. First, a declarative questionnaire was used in this study and no real-time monitoring or observation was conducted. Second, the study was confined only to 3 cities only, and more precise results can be obtained with multi-center and concurrent studies.

\section{References}

Abbot, J.M., Bryd-Bredbenner, C., Grasso, D. (2007). Know before you serve: Developing a food-allergy fact sheet. Cornell Hotel and Restaurant Administration Quarterly, 48, 274-283. https://doi.org/10.1177/0010880407302779

Ahuja, R., Sicherer, S.H. (2007). Food allergy management from the perspective of restaurant and food establishment personnel. Annals of Allergy, Asthma and Immunology, 98, 344-348.

https://doi.org/10.1016/S1081-1206(10)60880-0

Ansari-Lari, M., Soodbakhsh, S., Lakzadeh, L. (2010). Knowledge, attitudes and practices of workers on food hygienic practices in meat processing plants in Fars, Iran. Food Control, 21, 260-263.

https://doi.org/10.1016/j.foodcont.2009.06.003

Bailey, S., Kindratt, T.B., Smith, H., Readingi, D. (2014). Food allergy training event for restaurant staff; a pilot evaluation. Clinical and Translational Allergy, 4, 26-29.

https://doi.org/10.1186/2045-7022-4-26

Baser, F., Ture, H., Abubakirova, A., Sanlier, N., Cil, B. (2017). Structural modeling of the relationship among food safety knowledge, attitude and behavior of hotel staff in Turkey. Food Control, 73, 438-444.

https://doi.org/10.1016/j.foodcont.2016.08.032

Bock, S.A., Munoz-Furlong, A., Sampson, H.A. (2001). Fatalities due to anaphylactic reactions to food. Journal of Allergy and Clinical Immunology, 107, 191-193.

http://dx.doi.org/10.1067/mai.2001.112031

Boyce, J.I. (2012). Food allergies in developing and emerging economies: need for comprehensive data on prevalence rates. Clinical and Translational Allergy, 2(1), 25.

http://dx.doi.org/10.1186/2045-7022-2-25

Choi, J.H., Rajagopal, L. (2013). Food allergy knowledge, attitudes, practices and training of foodservice workers at a university foodservice operation in the Midwestern United States. Food Control, 31(2), 474-481.

http://dx.doi.org/10.1016/j.foodcont.2012.10.023

Clayton, D.A., Griffith, C.J., Price, P., Peters, A.C. (2002). Food handlers beliefs and self-reported practices. International Journal of Environmental Health Research, 12(1), 2539.

https://doi.org/10.1080/09603120120110031 
Common, L.A., Corrigan, C.J., Smith, H., Bailey, S., Harris, S., Holloway, J.A. (2013). How safe is yourcurry? Food allergy awareness of restaurant staff. Journal of Allergy and Therapy, $4,4$.

https://doi.org/10.4172/2155-6121.1000140

Dupuis, R., Meisel, Z., Grande, D., Strupp, E., Kounaves, S., Graves, A., Frasso, R., Cannuscio, C.C. (2016). Food allergy management among restaurant workers in a large US city. Food Control, 63, 147-157.

https://doi.org/10.1016/j.foodcont.2015.11.026

FARE (2020). Facts and statistics, available at: www.foodallergy.org/facts-and-stats (accessed 20 January 2020).

Gaspar-Marques, J., Carreiro-Martins, P., Papoila, A.L., Caires, I., Pedro, C., Araujo-Matins, J., Virella, D., Rosado-Pinto, J., Leiria-Pinto, P., Neuparth, N. (2014). Food allergy and anaphylaxis in infants and preschool-age children. Clinical Pediatrics, 53, 7.

http://dx.doi.org/10.1177/0009922814527502

Güler, N. (2019). Türkiye'de her 17 çocuktan birinde besin alerjisi görülüyor!, available at: https://www.milliyet.com.tr/pembenar/turkiye-de-her-17-cocuktan-birinde-besin-alerjisi-goruluyor-2870434 (accessed 12 Jaunary 2020).

Kwon, J., Lee, Y.M. (2012). Exploration of past experiences: attitudes and preventive behaviors of consumers with food allergies about dining out: a focus groupstudy. Food Protection Trends, 32, 736-746.

http://hdl.handle.net/2097/9791

Kwon, J., Lee, Y.M., Wen H. (2020). Knowledge, attitudes, and behaviors about dining out with food allergies: A crosssectional survey of restaurant customers in the United States. Food Control, 107.

https://doi.org/10.1016/j.foodcont.2019.106776

Lee, Y. M., Sozen, E. (2018). Who knows more about food allergies - restaurant managerial staff or employees? British Food Journal, 120(4), 876-890.

https://doi.org/10.1016/j.ijhm.2016.05.004

Lee, Y.M., Barker, G.C. (2016). Comparison of food allergy policies and training between Alabama (AL) and National Restaurant Industry. Journal of Culinary Science and Technology, 15(1), 1-16.

https://doi.org/10.1080/15428052.2016.1185071
Lee, Y.M., Sozen, E. (2016). Food allergy knowledge and training among restaurant employees. International Journal of Hospitality Management, 57, 52-59.

https://doi.org/10.1016/j.ijhm.2016.05.004

Lefevre, S., Abitan, L., Goetz, C., Frey, M., Ott, M., Blay, F. (2018). Multicenter survey of restaurant staff's knowledge of food allergy in Eastern France. Allergy Journal International, 28, 57-62.

https://doi.org/10.1007/s40629-018-0062-21-6

Lorcu, F. (2015). Örneklerle veri analizi spss uygulamalı. Ankara: Detay Publishing. ISBN: 9786054940899

Madsen, C. B., Crevel, R., Chan, C. H., Dubois, A. E. J., Galvin, D. A., Blok, B. M. J. F., et al. (2010). Food allergy: Stakeholder perspectives on acceptable risk. Regulatory Toxicology and Pharmacology, 57(2-3), 256-265.

http://dx.doi.org/10.1016/j.yrtph.2010.03.003

Mandabach, K.H., Ellsworth, A., Vanleeuwen, D. M., Blanch, G., Waters, H.L. (2005). Restaurant managers knowledge of food allergies. Journal of Culinary Science and Technology, 4(2-3), 63-77.

http://dx.doi.org/10.1300/J385v04n02 05

National Institute of Allergy and Infectious Diseases (2019). Food allergy, available at: www.niaid.nih.gov/diseases-conditions/food-allergy (accessed 2 June 2019).

Olivier, C.E. (2013). Food allergy. Journal of Allergy and Therapy, 4, 1-7.

https://doi.org/10.4172/2155-6121.S3-004

Sampson, H.A. (2004). Update on Food Allergy. Journal Allergy Clinical Immunology, 113, 805-819.

https://doi.org/10.1016/j.jaci.2004.03.014

Sapan, N., Esen, D., Tamay, Z., Akçakaya, N., Güler, N., Yazıcıoğlu, M., Karaman, Ö., Akçay, A., Öneş, U. (2013). Pediatric allergy and asthma academy, food allergy diagnosis and treatment protocol. Türk Pediatri Arşivi, 48(4), 270-274. https://doi.org/10.4274/tpa.2029

Seaman, P., Eves, A. (2010). Perceptions of hygiene training amongst food handlers, managers and training providers - A qualitative study. Food Control, 21, 1037-1041. https://doi.org/10.1016/j.foodcont.2009.12.024 
Seth, D., Poowutikul, P., Pansare, M., Kamat, D. (2020). Food allergy: a review. Pediatric Annals, 49(1), 50-58. https://doi.org/10.3928/19382359-20191206-01

Shafie, A.A., Azman, A.W. (2015). Assessment of knowledge, attitude and practice of food allergies among food handlers in the state of Penang, Malaysia. Public Health, 129(9), 1278-1284.

https://doi.org/10.1016/j.puhe.2015.03.016

Sicherer, S.H. (2011). Epidemiology of food allergy. Journal of Allergy and Clinical Immunology, 127(3), 594-602.

https://doi.org/10.1016/j.jaci.2013.11.020

Sicherer, S.H., Sampson H.A. (2014). Food allergy: epidemiology, pathogenesis, diagnosis, and treatment. Journal Allergy Clinical Immunology, 133(2), 291-307.

https://doi.org/10.1016/j.jaci.2013.11

Sogut, A., Kavut, A.B., Kartal, İ., Beyhun, E.N., Çayır, A., Mutlu, M., Ozkan, B. (2015). Food allergy knowledge and attitude of restaurant personnel in Turkey. International Forum of Allergy and Rhinology, 5(2), 157-161.

https://doi.org/10.1002/alr.21427

Soon, J.M. (2019). Food allergen knowledge, attitude and practices among UK consumers: A structural modelling approach. Food Research International, 120, 375-381. https://doi.org/10.1016/j.foodres.2019.03.008

Stjernat, M.L., Vetander, M., Wickman, M., Olin Lauritzen, S. (2014). The management of situated risk: a parental perspective on child food allergy. Health, 18(2), 130-145. https://doi.org/10.1177/1363459313481234

Tatlı, M., Akoglu, A. (2020). Food allergy knowledge, attitude and practices of restaurant employees in Istanbul, Turkey. Academic Food, 18(2), 125-134.

https://doi.org/10.24323/akademik-gida.758812

Ural, A., Kılıç, I. (2013). Bilimsel Araştırma Süreci ve SPSS ile Veri Analizi, Ankara: Detay Publishing. ISBN: 9789758969173

Wen, H., Kwon, J. (2017). Restaurant servers risk perceptions and risk communication-related behaviors when serving customers with food allergies in the U.S. International Journal of Hospitality Management, 64, 11-20.

https://doi.org/10.1016/j.ijhm.2017.03.009

Wham, C.A., Sharma, K.M. (2014). Knowledge of café and restaurant managers to provide a safe meal to food allergic consumers. Nutrition and Dietetics, 71(4), 265-269. https://doi.org/10.1111/1747-0080.12104 